\title{
GAUCHER'S DISEASE; A CLINICAL AND PATHOLOGICAL STUDY.
}

\author{
BY
}

STANLEY GRAHAM, M.D., AND JOHN W. S. BLACKLOCK, M.B., Ch.B. (From the Medical Department of the Royal Hospital for Sick Children, and the Pathological Departments of the University, Glasgow, and of the Royal Hospital for sick (hildren, Glasgou.)

Splenic enlargement in infancy and early childhood is a common clinical finding but the diagnosis of its cause is often a problem of great difficulty. In the present communication, it is not our intention to discuss the merits of any classification, or the question of differential diagnosis, but rather to bring forward a series of cases illustrating a definite clinical entity, which has, as one of its cardinal signs, a splenomegaly, namely, Gaucher's disease.

In 1882, Gaucher ( $\left.{ }^{1}\right)$ described the first case of the condition which bears his name, believing it to be an epithelioma of the spleen. It was not until thirteen years later that Collier $\left({ }^{2}\right)$ in this country and Picou and Ramond $\left({ }^{3}\right)$ in France described the next cases. In 1900, Bovaird $\left(^{4}\right)$ described the first of the American cases: he believed the large cells which are characteristic of the condition to be endothelial in origin. In 1904, Brill and Mandelbaum ( ${ }^{5}$ ) reported the original case of their series, describing for the first time the occurrence of the large cells in the bone-marrow, and it is to these writers that we owe a considerable amount of our knowledge concerning the clinical and pathological nature of the disease. Since then, many cases have been recorded. Schlagenhaufer $\left({ }^{6}\right)$ reported the first of the German cases in 1907 and referred to it as a disease of the lymphatic-hæmatopoietic system. In 1919, Mandelbaum ( $\left.{ }^{7}\right)$ stated that up to that time (1919), there were 21 undoubted examples in the literature, many more having been reported as such but discarded by him on the grounds of insufficient evidence. To this group of unproven cases belong those reported by Knox, Wahl and Schmeisser $\left({ }^{8}\right)$ as well as the two sisters reported by De Lange and Schippers $\left({ }^{9}\right)$. It is only fair to state that one year after their first publication, these last two authors again published a report $\left({ }^{10}\right)$ stating that their original diagnosis was incorrect. Pick (11), in 1926, collected 39 cases, 5 of which were seen and reported by him personally. He agrees with Mandelbaum in discarding certain cases in which the evidence in favour of Gaucher's disease was not complete. Of the 39 cases in his series more than half ( 22 as compared with 17 ) have been reported during the last seven years, that is, since Mandelbaum's series in 1919.

We have been fortunate in having had under our observation during the last three years, four cases of Gaucher's disease, and through the kindness of Mr. MacLennan, the spleen from a fifth case was obtained for pathological study.

\section{Report of Cases.}

CASE 1. M.F., female, aged 18 months; only child; full-term baby, healthy at birth and breast-fed for one month, then dried milk till one year, and since then mixed diet. She cut her first tooth at seven months and was able to sit up at nine months. She had always been a pale baby. When 11 months old, she went off her food and became much paler. When 
14 months old, it was noticed that the abdomen was becoming much larger. She was seen shortly afterwards by a physician who suspected abdominal tuberculosis and referred the case to hospital.

Physical Examination on Admission. A pale, wasted infant, weighing $7 \mathrm{~kg}$. There was a faint but definite icteroid tint of the skin. In comparison with the chest the abdomen appeared to be greatly enlarged and on palpation there could be felt an enlarged spleen completely filling the left half of the abdomen, extending two centimetres to the right of the umbilicus and well below the iliac crest. The liver also was enlarged, the lower border being six centimetres below the right costal margin. The teeth were mainly decayed stumps, and the gums were spongy and bled readily. The examination revealed nothing otherwise relevant, the Wassermann reaction being negative, as also the $v$. Pirquet tuberculin test. The blood examination on admission was as follows :-

\begin{tabular}{|c|c|c|c|c|c|c|}
\hline Hæmoglobin & $\cdots$ & . & $\ldots$ & $\ldots$ & . & $20 \%$ \\
\hline Red cells . . & . & . . & . & . & . & $2,090,000$ \\
\hline White cells & . & $\because$ & $\ldots$ & . & . & 8,600 \\
\hline Colour index & . & $\therefore$ & . & . & . & $0 \cdot 6$ \\
\hline \multicolumn{7}{|c|}{ Differential count (of 200 cells) :- } \\
\hline \multicolumn{3}{|c|}{ Polymorphonuclears } & $\because$ & . & . & $31 \%$ \\
\hline \multicolumn{2}{|c|}{ Lymphocytes } & . & $\therefore$ & . & . & $62 \%$ \\
\hline \multicolumn{2}{|c|}{ Eosinophiles } & .. & $\cdots$ & $\cdots$ & $\cdots$ & $2 \%$ \\
\hline \multicolumn{2}{|c|}{ Transitionals } & $\cdots$ & . & . & . & $3 \%$ \\
\hline \multicolumn{2}{|c|}{ Myelocytes } & .. & $\ldots$ & $\ldots$ & $\ldots$ & $2 \%$ \\
\hline
\end{tabular}

Slight anisocytosis and poikilocytosis were noted but no nucleated red cells were seen.

Progress. Five days after admission, the leucocytes numbered 4,800, remaining between 4,000 and 6,000 until death. The baby was transfused twice, 220 cc. being given on the first occasion and $260 \mathrm{cc}$. on the second. After each, there was considerable oozing of blood from the transfusion wound. There was occasionally slight irregular fever but for the most part the course was afebrile. After one month in hospital, the patient had lost weight, was refusing food and generally had lost ground. The blood examination at this time was as follows :-

$$
\begin{aligned}
& \begin{array}{lllllll}
\text { Hæmoglobin } & \ldots & \ldots & \ldots & \ldots & \ldots & 68 \%
\end{array} \\
& \begin{array}{llllllll}
\text { Red cells } & \ldots & \ldots & \ldots & \ldots & \ldots & \ldots & 4,050,000
\end{array} \\
& \begin{array}{lllllll}
\text { White cells } & \ldots & \ldots & \ldots & \ldots & \ldots & 5,400
\end{array} \\
& \begin{array}{lllllll}
\text { Colour index } & \ldots & \ldots & \ldots & \ldots & \ldots & 1 \cdot 0
\end{array}
\end{aligned}
$$

The smears differed in no way from those previously described, except that the myelocytes numbered only 0.5 per cent. Two days later the baby suddenly collapsed and had a convulsion which ended fatally.

Post-mortem Examination. No gross lesion was found in the thoracic viscera. The bronchial and tracheal glands were not enlarged and the thymus was small. On examination of the abdomen, no ascites was present. The liver, which weighed $395 \mathrm{grm}$., was of a pale brownish colour, the cut surface showing a fine cirrhosis and mottling due to small pale areas being scattered throughout the substance of the organ and bearing no definite relation to the portal tracts. At places this pale tissue formed larger nodules about the size of peas. The naked-eye picture did not suggest a leukæmic infiltration and the cut surface gave a slight hæmosiderin reaction. The spleen was much enlarged and weighed 500 grm., its greatest length being $15 \mathrm{~cm}$., and breadth $6.5 \mathrm{~cm}$. There was no evidence of perisplenitis. The cut surface of the organ was of a greyish-brown colour and markedly mottled, the appearance being very like that of coarse sea-sand. The Malpighian bodies were not prominent and the cut surface gave a slight hæmosiderin reaction. The kidneys which together weighed $34 \mathrm{grm}$. were pale and showed a slight fatty change. The mesenteric and retro-peritoneal glands were enlarged, being mostly of the hæmolymph type. The largest glands (about the size of almonds) were found near the upper part of the mesentery. No evidence of tuberculosis was noted in any of these glands which were discrete, of a uniform consistence and pinkish in colour. No evidence of disease was found in the stomach or bowel, the lymphoid tissue in the latter structure showing no gross 
change. No lesion was found in the bones of the skull, in the middle ears, or in the brain. The marrow of the femur appeared normal for a child of this age, though here and there throughout its substance small pale areas of the size of a pin's head were found.

Histology. On microscopic examination of the spleen the pulp spaces were found to be packed with large cells 20 to $40 \mu$ in diameter with a clear protoplasm which on examination with a high power showed a finely reticulated appearance. The nuclei of these cells were small and stained darkly, occasionally a cell showing two or more nuclei being observed. Vacuolation of the protoplasm of the cells was rare and they seldom showed any phagocytosis of red cells and only an occasional mitotic figure was seen. Practically the whole of the splenic pulp had been replaced by these cells, the small sinusoids being pressed on and occasionally containing a large Gaucher cell (Fig. 1 and 17); the capsule of the spleen was not invaded. The Malpighian bodies were small, Gaucher cells being found in the peripheral parts of these structures as well as in the germ centres which had almost entirely been replaced by the large cells (Fig. 2). In places, masses of Gaucher célls were noted in the lumina of branches of the splenic vein (Fig. 3). A point to which Pick ( $\left.{ }^{12}\right)$ draws attention was also seen in this case, namely, the occurrence of the Gaucher cells in the adventitial coat of the small vessels (Fig. 4). Pick suggests that the large cells may take origin from the adventitial cells but in the present series this was the only case in which the appearance was noted. The staining of these large cells by Mallory's method is very typical and serves as a quick method for picking out the cells in other tissues as the protoplasm stains bluish and shows a fine reticulum which is stained more by the fuchsin: this staining is looked upon as diagnostic by Epstein $\left({ }^{13}\right)$ who has investigated the disease chemically. These large cells were also in close relationship to reticulum (Fig. 5), and what appeared to be transition stages between Gaucher cells and reticulum cells and fibres were observed. A few of the cells showed a slight diffuse reaction for iron. No areas of necrosis or fibrosis were found in any of the sections examined. No glycogen was found in sections of tissue fixed in alcohol and cut in celloidin.

On microscopic examination of the liver a fine irregular cirrhosis was present, the area around the lobular branches of the hepatic veins being replaced by fine fibrous tissue and masses of Gaucher cells (Fig. 7) which were also found in the sinusoids between the remaining liver cell; clustered around the portal tracts (Fig. 8). There was but slight proliferation of the bile ducts, while in places necrosis had occurred in masses of these large cells. It was only occasionally that a few Gaucher cells were found in the intra-hepatic branches of the portal vein, and invasion of the portal tracts (Fig. 6) was seldom noted. Another interesting feature of the disease in the liver was the small nests of cells clustered around very fine capillary vessels. The reticulated appearance of the cells was well marked in the liver, and some of the cells gave a slight diffuse reaction for iron. As in the spleen, a close relationship to reticulum on the part of these cells was noted (Fig. 9).

The lymphatic glands, noted to be enlarged at the autopsy, were found on examination to be of the hæmolymph type, Gaucher cells being scattered irregularly throughout their substance (Fig. 10). The large cells were not present in the peripheral lymph sinuses, such as one is accustomed to see in malignant disease with glandular metastases. A few Gaucher cells were found in the germ centres but this was not as marked as in the spleen. The cells gave no reaction for iron as did the spleen and liver, though, as in both these organs, they were still intimately associated with reticulum (Fig. 11).

On examination of the bone-marrow, small clusters of Gaucher cells, which were slightly smaller than in the other situations, were found, and these showed the same histological char. acters as in the situations already described (Fig. 12). Some of the large cells showed slight phagocytosis of the red cells and here again, as in the other tissues already examined, they were in close relation to reticulum (Fig. 13).

No Gaucher cells were found in sections of the lung, bronchial glands, kidneys, suprarenals, ovaries, Peyer's patches, pituitary, thyroid, thymus or superficial lymphatic glands.

CASE 2. G.L., boy, aged 6 years, second child in family of four. 'This boy is a brother of R.L. (Case 3). None of the other members of the family was noted to have an enlarged spleen. He was a full term infant and throve and developed normally. When four years old, he had 
measles and whooping-cough. For 18 months previous to admission he had complained of tiredness on exertion and had been very constipated.

Physical Examination on Admission. A fair-sized boy with adenoid facies and marked frontal bossing. The abdomen was full and the spleen was enlarged, the lower border being palpable 4 centimetres below the costal margin. The lower border of the liver was 8 centimetres below the right costal margin. The teeth were very bad, and the gums spongy and bled readily. Otherwise the physical examination revealed nothing of significance. The blood examination waj as follows :-

$$
\begin{array}{llllllc}
\text { Hæmoglobin } & \ldots & \ldots & \ldots & \ldots & \ldots & 58 \% \\
\text { Red cells } . . & \ldots & \ldots & \ldots & \ldots & \ldots & 3,540,000 \\
\text { White cells } & \ldots & \ldots & \ldots & \ldots & \ldots & 5,700 \\
\text { Colour index } & \ldots & \ldots & \ldots & \ldots & \ldots & 1 \cdot 0
\end{array}
$$

In films no abnormal cells were seen. The Wassermann reaction was negative and the v.Pirquet test positive. There was no appreciable rise in the blood sugar after the ingestion of lævulose. Splenic tissue was obtained by means of puncture and the clinical diagnosis of Gaucher's disease confirmed on histological examination.

Progress. No appreciable change in the child's condition took place during his residence in hospital. There was no fever and, on the whole, the boy.could not be considered ill. Four weeks after admission he was transferred to the surgical wards where splenectomy was successfully performed. At the operation it was noted that the liver was of a brownish colour and showed a slight cirrhosis : no piece was obtained for microscopic examination.

Pathology. Tissue obtained by Splenic Puncture. In films made from this material and stained with hæmatoxylin and eosin, many large cells were seen with a clear protoplasm in which a slight granular appearance could be made out and which contained one or more nuclei (Fig. 20). The size of the large cells as compared with the red cells is well seen in the figure. Paraffin sections were made as is afterwards described, and on examination showed small pieces of splenic tissue in which the pulp spaces were packed with large Gaucher cells (Fig. 19).

Spleen. The cut surface of the spleen immediately after removal was of a reddish-brown colcur, the Malpighian bodies being prominent though widely separated from each other. The capsule was smooth. The organ weighed 230 grm., its greatest length being $14 \mathrm{~cm}$. and breadth $4 \mathrm{~cm}$. On histological examination of the spleen, the cellularity of the organ was not as marked as in the first case. The Malpighian bodies were larger than usual, the enlargement being due chiefly to a hyperplasia of the germ-centres in which a few Gaucher cells were present (Fig. 14). The Gaucher cells were similar in their characters and relations to those of the first case, but there was no invasion of the adventitial coat of the blood vessels and none of the cells gave a reaction for iron. Gaucher cells were seldom found in the lumina of the branches of the splenic vein. In this case the relationship of the cells to reticulum was particularly close, especially i. the Malpighian bodies, where the appearance suggested that the cells were arising from reticular cells.

CASE 3. R.L., boy of ten years, oldest in family of four, healthy at birth and throve well in infancy. During the second year of life he had several attacks of diarrhœa, and at 3 years measles followed by otitis media which lasted for several years. At four years of age, he had chicken-pox, at seven years and again at eight years, pneumonia. His tonsils were removed after the second attack of pneumonia. For six months previous to admission he suffered from diarrhœa and often complained of pain in the left side of the abdomen. His mother noticed that he tired easily and became short of breath on the slightest exertion. For three months the pain in the side had been much worse and it was for this complaint that medical advice was sought.

Physical Examination on Admission. A fair-sized boy with adenoid facies and well-marked pigeon breast. The fingers and toes were clubbed and cyanosed. The abdomen was large and on the left side the spleen extended down to the iliac crest and across the abdomen to within two centimetres of the umbilicus. The lower border of the liver was eight centimetres below the right costal margin. Examination of the heart and lungs showed nothing abnormal to account for the cyanosis and clubbing of the fingers. The teeth were carious and the gums 
were spongy and bleeding. The lips also bled readily. The blood examination on admission was as follows :-

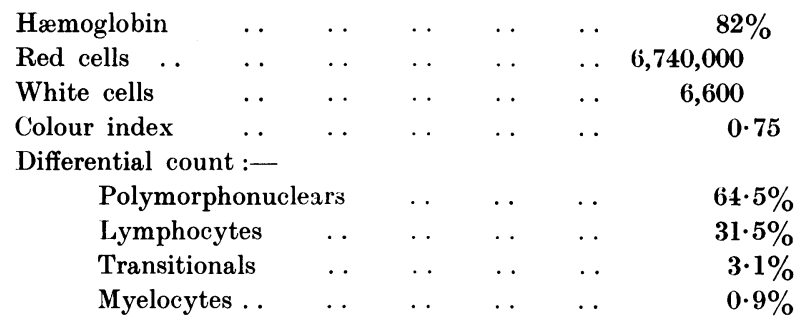

There was no abnormality in shape or staining of the red cells and their fragility was not increased The Wassermann reaction was negative. There was no rise in the blood sugar after the ingestion of lævulose and no rise in the leucocytes after the ingestion of protein (milk).

Progress. The condition did not alter during residence in hospital. There was no complaint of pain in the side but the patient was confined to bed. After the extraction of some carious teeth difficulty was experienced in controlling the oozing of blood from the gums. After one month in hospital he was transferred to the surgical ward for splenectomy, which was performed successfully a few days later.

Pathological Report. The spleen, received immediately after operation, weighed $\mathbf{7 4 4}$ grm., its greatest length being twenty centimetres and breadth, eight centimetres. The organ was of a brownish colour and the capsule was smooth. On cutting into the organ, the cut surface showed the Malpighian bodies widely separated from each other by a reddish-brown homogeneous soft pulp.

Histology. On microscopic examination the lesion in the spleen was not as cellular as in the second case though the histological picture was much the same except that the Malpighian bodies were not so hyperplastic (Fig. 15), and in these situations the Gaucher cells were found in very close relation to the reticulum.

CASE 4. M.S., girl of ten years; family history negative; healthy at birth and breast-fed until ten months of age. With the exception of measles at three years and whooping-cough at five years, she was apparently well until fourteen months previous to admission, when she had a febrile illness accompanied by jaundice which was looked upon by her physician as pneumonia. All signs and symptoms cleared up except the jaundice. During the fourteen months she had two similar attacks, each lasting from a fortnight to three weeks. Between the attacks she seemed to be perfectly well, and though jaundiced, attended school.

Physical Examination on Admission. A well-developed and well-nourished child with a definite yellowish tinge of the skin and conjunctivæ. The mucous membranes were of good colour. The teeth were carious, and the gums were spongy and bled readily. The abdomen was large, due to the size of the spleen which was palpable eight centimetres below the left costal margin. The liver was palpable two finger breadths below the right costal margin. The examination otherwise revealed nothing of note.

The Wassermann reaction was negative. The v. Pirquet tuberculin test was positive. The blood examination was as follows:-

\begin{tabular}{|c|c|c|c|c|c|c|}
\hline Hæmoglobin & $\cdots$ & . & $\ldots$ & $\ldots$ & $\ldots$ & $62 \%$ \\
\hline Red cells .. & . & . & $\cdots$ & $\cdots$ & .. & $3,520,000$ \\
\hline White cells & .. & . & . & $\cdots$ & .. & 6,400 \\
\hline Colour index & .. & .. & . . & . & .. & $1 \cdot 0$ \\
\hline \multicolumn{7}{|c|}{ Differential count :- } \\
\hline \multicolumn{3}{|c|}{ Polymorphonuclears } & $\cdots$ & . & . & $62 \cdot 0 \%$ \\
\hline \multicolumn{3}{|c|}{ Lymphocytes } & . & . & .. & $31 \cdot 3 \%$ \\
\hline \multicolumn{3}{|c|}{ Large Mononuclears } & . & . & . & $1 \cdot 6 \%$ \\
\hline \multicolumn{2}{|c|}{ Mast cells .. } & . & . & . & . & $1 \cdot 0 \%$ \\
\hline \multicolumn{2}{|c|}{ Transitionals } & . & . & . & .. & $3.0 \%$ \\
\hline \multicolumn{2}{|c|}{ Myelocytes .. } & .. & .. & .. & -. & $1.0 \%$ \\
\hline
\end{tabular}


The size and staining of the red cells were normal, no nucleated red cells being present. The fragility of the red cells was within normal limits. The stools varied in colour, being at times distinctly like those of catarrhal jaundice, yet the urine was on all occasions free from bile although it contained a considerable amount of urobilin. The blood contained 2.5 units of bilirubin and the Van den Bergh test gave a biphasic reaction. The blood sugar rose from 0.112 per cent. to 0.136 per cent., one hour after the ingestion of fifteen grm. of lævulose. There was no rise in the leucocyte count after the ingestion of protein. After a period of two weeks in hospital, splenectomy was performed.

Pathological Report. The spleen, obtained immediately after operation, weighed 383 grm., its greatest length being $15 \mathrm{~cm}$. and breadth $4.5 \mathrm{~cm}$. The organ was of a brownish colour and the capsule was smooth. The cut surface differed from that seen in the three preceding cases, the Malpighian bodies not being prominent, and scattered through the reddish-brown pulp were numerous firm reddish areas suggestive of young connective ti ssue with softer yellowishgrey areas of necrosis. These areas were usually small and were not observed immediately under the capsule.

Histology. On microscopic examination there was present a greater degree of cellularity than in the case of the spleen of the two brothers, G.L., and R.L., but not to such an extent as in the first case, M.F. It is of interest to note that more multinucleated Gaucher cells were seen in sections in this case than in any of the others. The Malpighian bodies were still present and showed Gaucher cells in their peripheral portions and in their germ-centres. In addition, early fibrosis was present in places, the Gaucher cells no longer lying in the typically round pulp spaces (Fig. 16), but arranged in long columns between strands of fibrous tissue. At other places areas of more advanced fibrosis in which no Gaucher cells could be made out were present, such patches being chiefly in relation to vessels, the adventitial coats of which showed much fibrous thickening (Fig. 16). Areas of necrosis were also scattered throughout the sections and around these fibrosis was taking place. There were no Gaucher cells found in the thickened adventitial walls of the blood-vessels, though in the lumina of some of them a few Gaucher cells were present. The Gaucher cells near the areas of fibrosis and necrosis showed a slight diffuse reaction for iron while the endothelial cells lining the small sinusoids showed darker blue iron pigment which was in the form of small granules. The relation of the Gaucher cells to the reticulum was still close though this structure was becoming thicker and at places showed a deposit of collagen.

CASE 5. Miss R., aged 38 years. During the examination of the patient on account of a suspected chest condition the spleen was noted to be greatly enlarged, the free border extending about two centimetres to the right of the mid-line. The liver was slightly enlarged. It was also observed that the fronts of both legs were pigmented as if habitually scorched. Further details regarding the history are not available ex.ept that the patient's sister also has an enlarged spleen which, however, has never caused her any inconvenience. Splenectomy was successfully performed by Mr. MacLennan.

Pathological Report. The spleen weighed 2,495 grm. Its naked-eye appearance was similar to that in the last case although the fibrotic and necrotic areas were larger.

Histology. On microscopic examination the sections were less cellular as compared with the preceding case, the Malpighian bodies were still present, however, and Gaucher cells were found in their peripheral portions and germ centres. Large areas of fibrosis with hyaline and calcareous change were irregularly scattered throughout the sections, some of the blocks showing very little Gaucher tissue (Fig. 18). The adventitia of the vessels was greatly thickened and in general the fibrosis, as in Case IV, started in relation to the vessels, except in areas where necrosis had occurred in masses of Gaucher cells. The iron reactions and reticulum staining were similar to those of the preceding case.

\section{Symptomatology.}

Owing to the comparative rarity of Gaucher's disease the clinical manifestations have been considered more or less in detail. 
Familial Nature. Collier ( $\left.{ }^{2}\right)$ first reported the occurrence of this disease in more than one member of the same family. The case recorded by him was that of a boy who died at the age of six years and whose sister had died several years previously of a similar type of splenic enlargement. Although this case is accepted from the histological picture described as being that of Gaucher's disease, no reference is made by Collier to Gaucher's original description. Pick ( ${ }^{11}$ ) states that in one-third of the reported cases, there has been a history of more than one child in the family suffering from the disease. So far, however, no case has been reported in which either parent was affected. Case 2 and Case 3 of this series are brothers and in the fifth case, as has been mentioned, a sister is also probably suffering from a similar condition.

Sex Distribution. The condition is slightly more common in females. Of forty-four reported cases, including the five detailed above, the disease is found to have occurred in twenty-eight females and sixteen males.

Onset. The onset is probably always insidious. Often the discovery of the splenic enlargement is made during the routine examination of the patient for some complaint in no way associated with the splenomegaly (Cases 2 and 5), or, as in Case 1, medical advice may be sought because of the steadily increasing size of the abdomen. Pain in the left side (Case 3) has also been frequently described and is said to be due to a localised perisplenitis, but in some cases it might be more correctly described as discomfort due to the size of the tumour. Also, some cases have cuine under the notice of the surgeon because of pathological fractures of the long bones.

Age at Onset. As the onset is insidious, it is impossible in many cases to state exactly when the condition began. In Case 1, the moiher stated that the patient was always a pale baby, although when eleven months old she became much paler. In Cases 2 and 3, it is impossible to say when the trouble started, and especially is this so in the case of R. L. (Case 2), in whom the enlargement was discovered during a routine examination. In Case 4, the condition had apparently begun fourteen months previously. Although Gaucher's disease is said to begin in early childhood, it would appear that a diagnosis is not usually arrived at until a much later period in life. Of 44 cases, only 18 were under fifteen years of age when they first came under observation, and in 19 cases, the age was thirty years or over. The youngest case reported is that of an infant of eight months who died of broncho-pneumonia and enteritis. Two cases have been reported at the age of one year. M. F. (Case 1) eighteen months old, is the next youngest. Pick has recorded the occurrence of the condition in two brothers, aged 45 and 56 years. When one remembers that the disease is not, at least for many years, crippling, and in the majority of cases never interferes with the patient's work, it is readily understood why the diagnosis is not made earlier.

Spleen and Lymph-glands. Splenic enlargement in Gaucher's disease is always present and is slowly progressive. At times it may assume tremendous proportions as in Case 1, where the weight of the spleen was 500 grammes in a child weighing seven kilogrammes. In the case reported by Collier, the actual weight of the spleen was $4 \mathrm{lb} .2 \mathrm{oz}$. in a child weighing $23 \mathrm{lb}$.--roughly one-sixth 


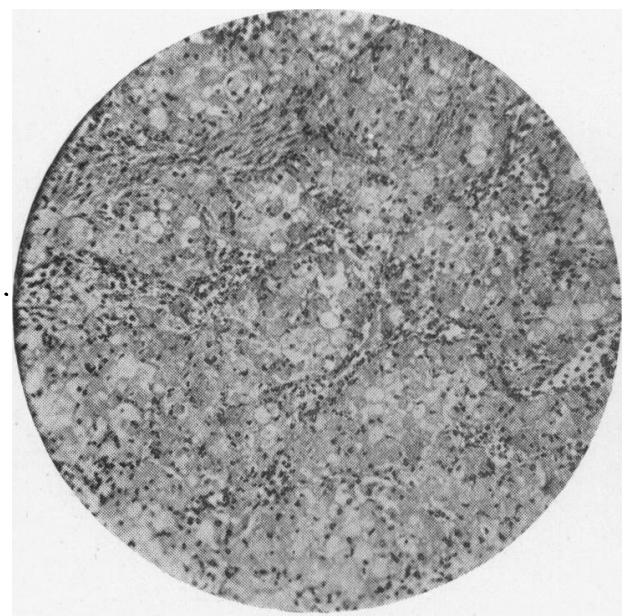

FIG. 1.

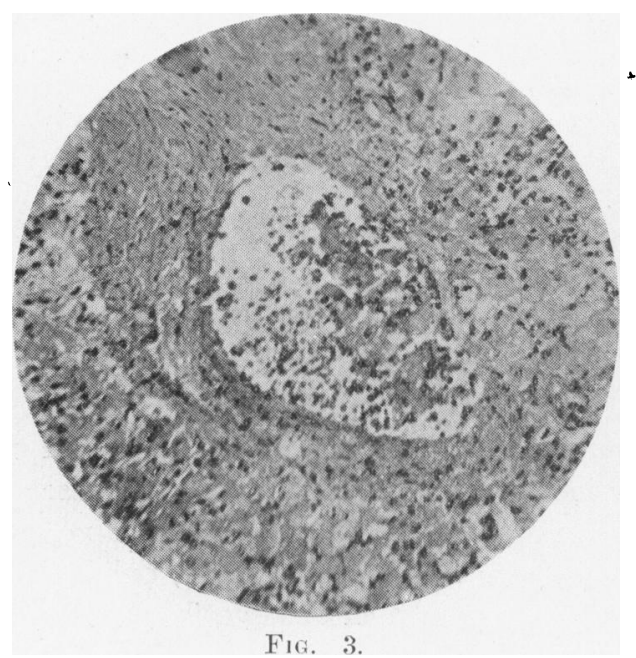

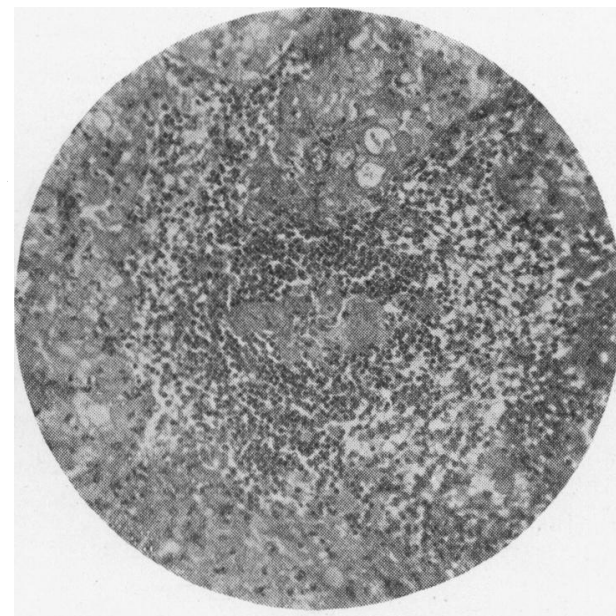

FIs: 2.

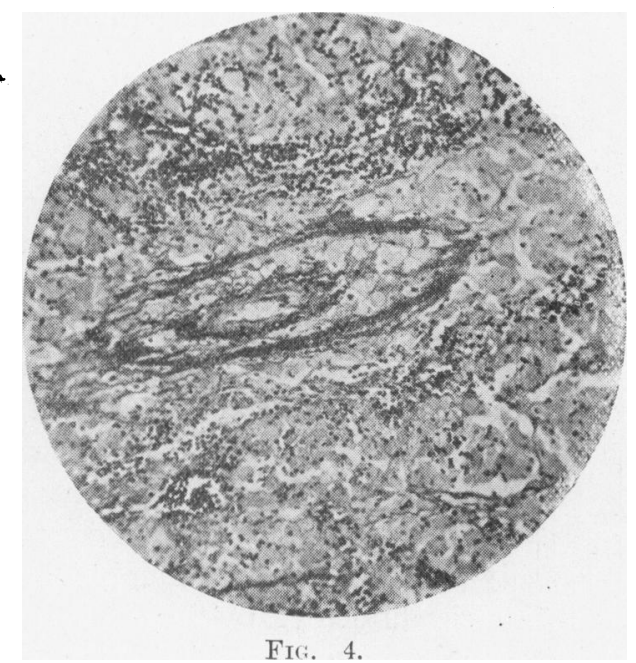

FIG. 4.

The pulp spaces are seen to be packed with large cells which have a clear protoplasm and a small, darkly-staining nucleus. The venous sinuses are pressed upon and some contain a few large cells. (Iron hæmatoxylin.)

Fig. 2.-Section of Spleen from Case 1 (M.F.).

The germ centre of the Malpighian body, which is small, has been replaced by Gaucher cells. (Hæmatoxylin and Eosin.)

Fig. 3.-Section of Spleen from Case 1 (M.F.).

A clump of Gaucher cells is noted in a vein in the substance of the spleen. (Hæmatoxylin and Eosin.)

Fig. 4. - Section of Spleen from Case 1 (M.F.).

Numerous Gaucher cells are observed in the adventitial coat of a small vessel in the substance of the spleen. (Iron hæmatoxylin.) 

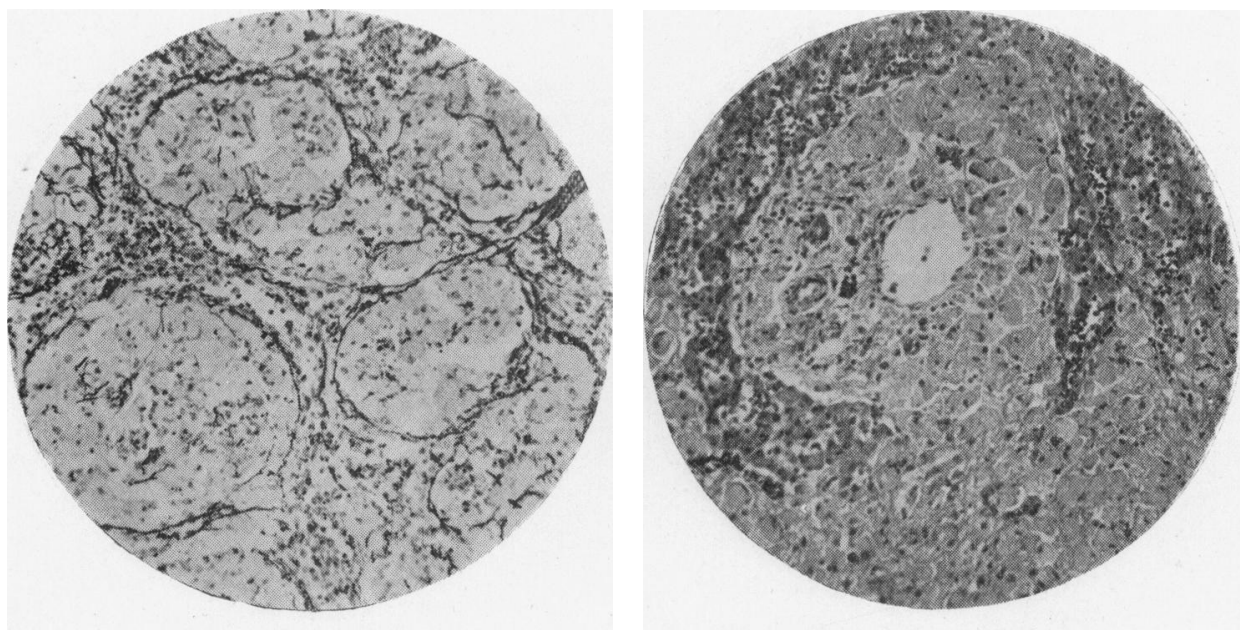

Fif. 5.

Fig. 6.

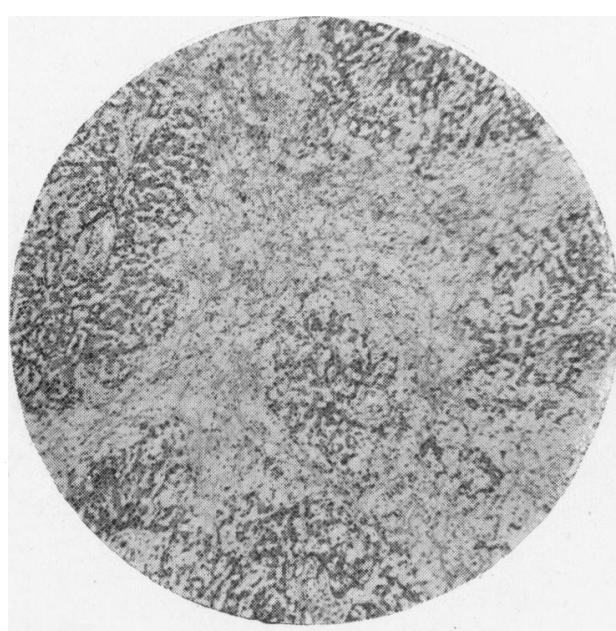

Fig. 7 .

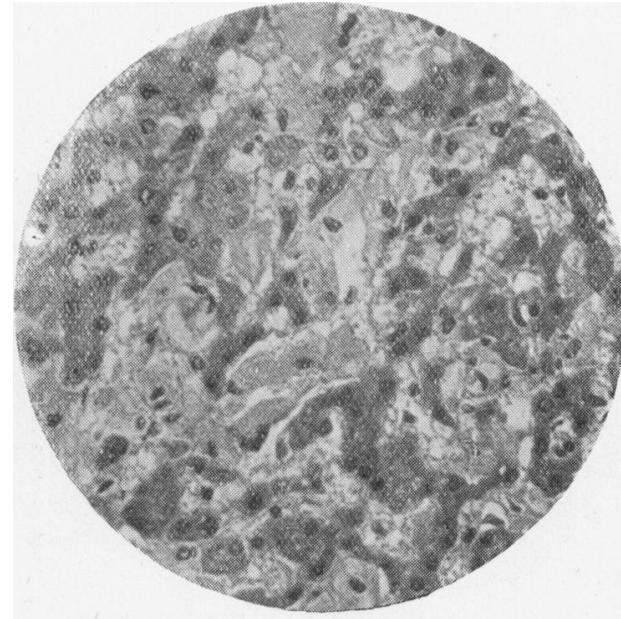

Fig. 8.

Fig. 5.-Section of Spleen from Case 1 (M.F.).

The section has been stained by Bielschowsky's method and shows darkly-staining reticular fibres surrounding the pulp spaces, the Gaucher cells being in intimate relationship to numerous fine fibres which run into the spaces.

Fig. 6.-Section of Liver from CaSe 1 (M.F.).

Numerous large cells are seen in a small portal tract. . (Hæmatoxylin and Eosin).

Fig. 7.-Section of Liver from Case 1 (M.F.).

Gaucher cells and fine fibrous tissue are seen replacing the central portions of the liver lobules, the remaining liver cells being clustered around the portal tracts. (Iron hæmatoxylin.)

Fig. 8. - Section of Liver from Case 1 (M.F.).

A high power view showing the large Gaucher cells in the liver sinusoids. (Hæmatoxylin and Eosin.) 


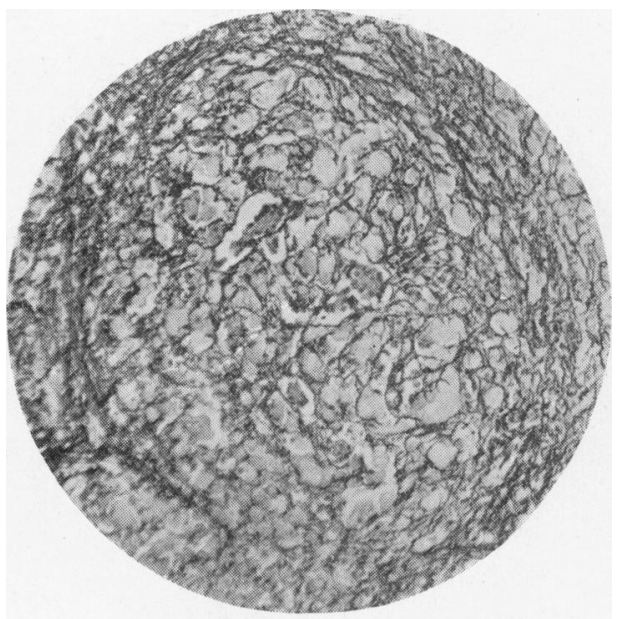

Fici. 9.

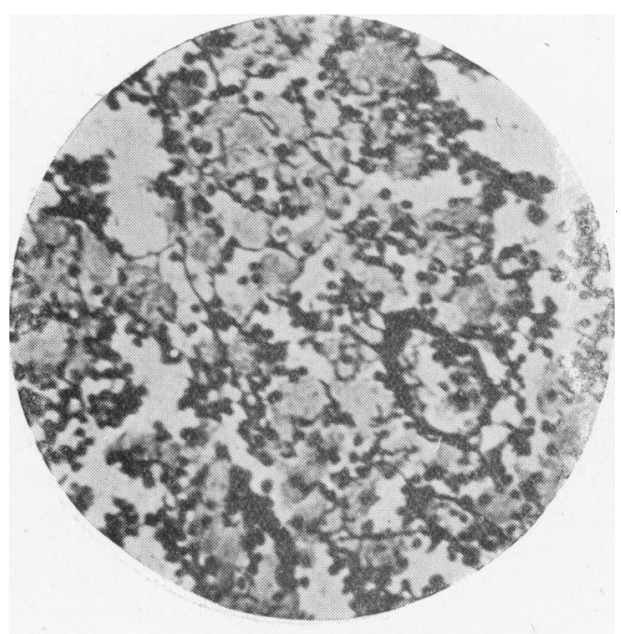

FIG. 11 .

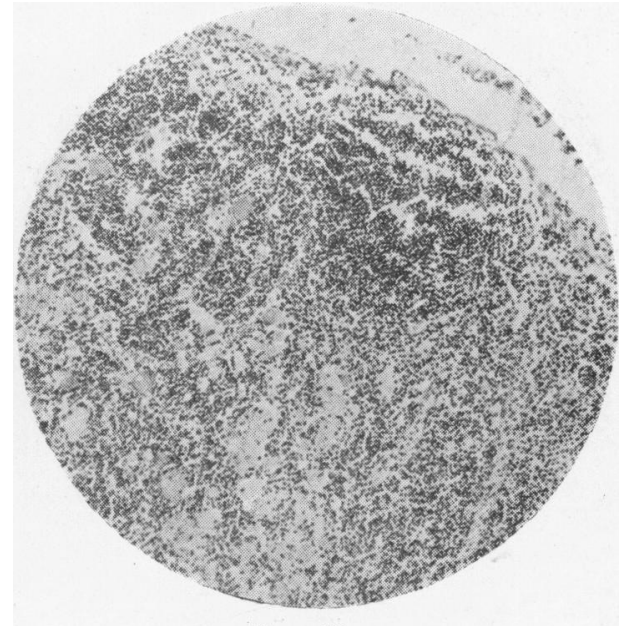

FIG. 10.

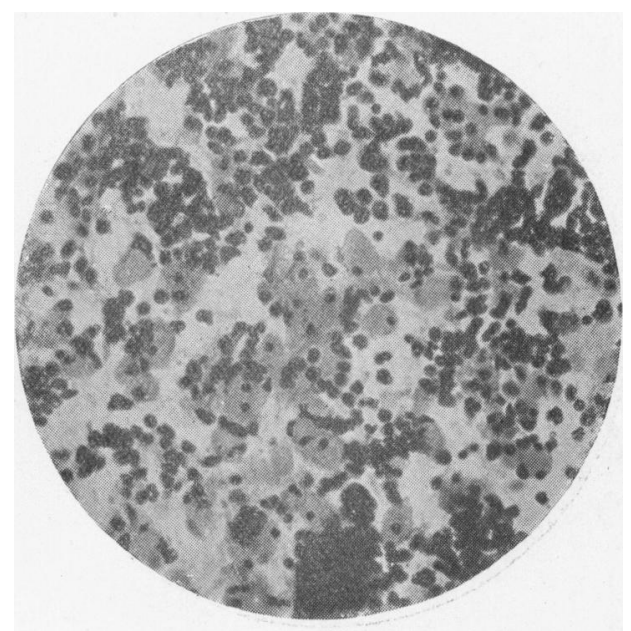

FI 12.

The section has been stained by Bielschowsky's method and shows the hyperplastic reticulum which is in intimate relationship to the Gaucher cells and in places completely surrounds single cells.

Fig. 10.-Section of Mesenteric Gland from Case 1 (M.F.).

The large cells are seen to be scattered throughout the substance of the gland; the peripheral sinus is free. (Hæmatoxylin and Eosin.)

Fig. 11.-Section of Mesenteric Gland from. Case 1 (M.F.).

The section has been stained by Bielschowsky's method and shows the large Gaucher cells in close relationship to the darkly-staining reticular fibres.

Fig. 12.-Section of Bone Marrow from Case 1 (M.F.).

A clump of Gaucher cells is seen in the substance of the marrow. (Hæmatoxylin and Eosin.) 


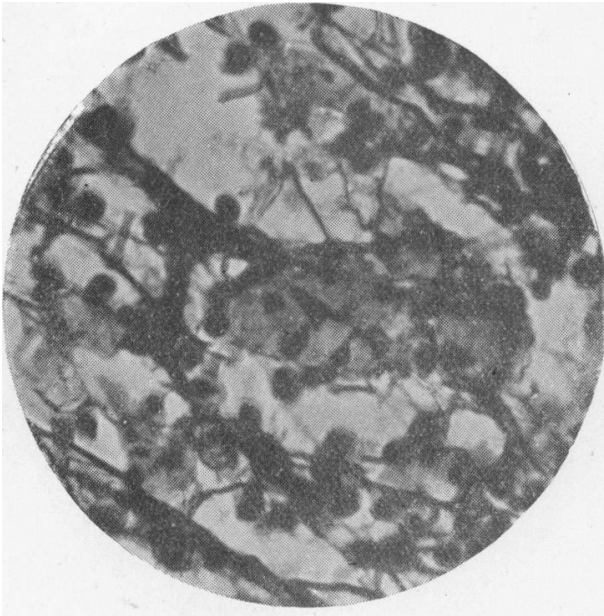

Fig. 13.

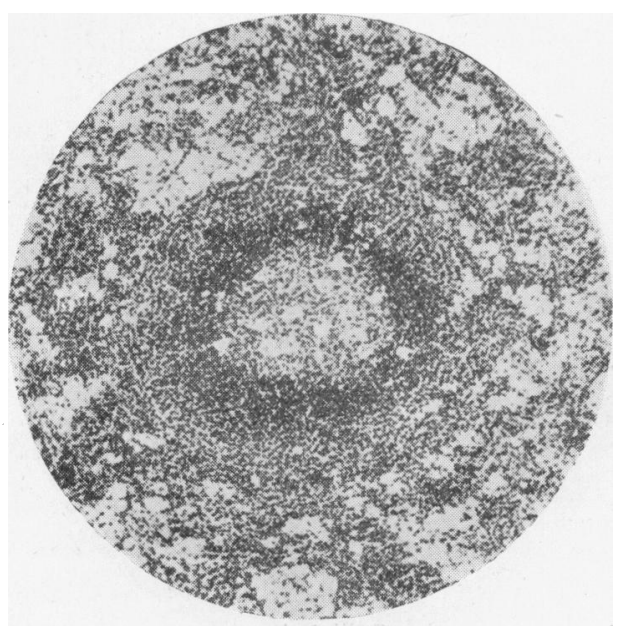

FIG. 15.

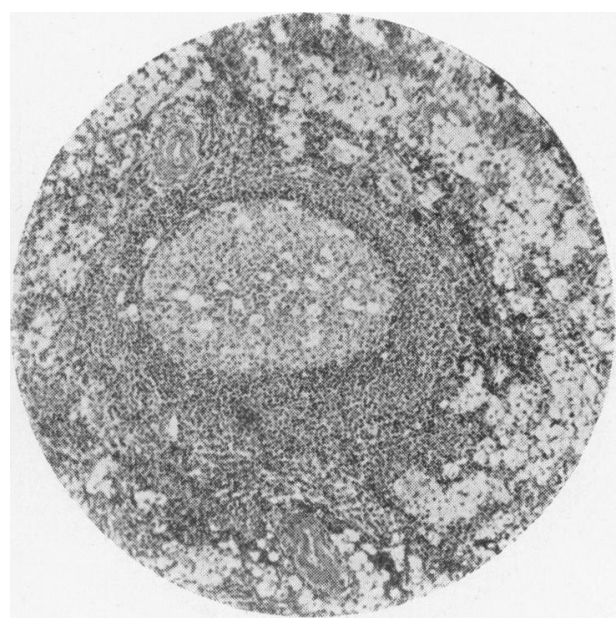

Fig. 14.

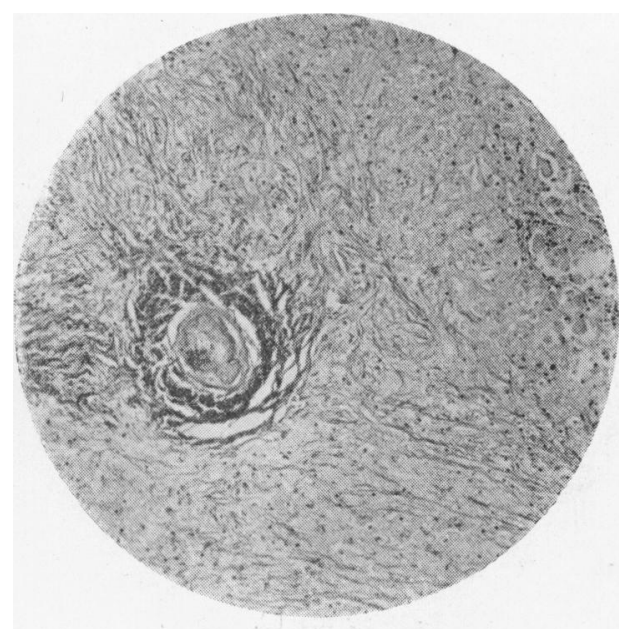

FIG. 16.

Fig. 13.-Section of Marrow from (ase l (M.F.).

The section has been stained by Bielschowsky's method and shows the close relationship of large cells to the reticulum.

Fig. 14.--Section of Spleen from Case 2 (G.L.).

The Malpighian bodies are seen to be markedly hyperplastic and numerous Gaucher cells are present in the germ centres and in the surrounding zone of lymphocytes. (Hæmatoxylin and Eosin.)

Fig. 15.-Section of Spleen from Case 3 (R.L.).

The Malpighian bodies are not so hyperplastic as in Case 2 ; Gaucher cells are seen in the germ centres and surrounding zone of lymphocytes. (Hæmatoxylin and Eosin).

Fig. 16.-Section of Spleen from Case 4 (M.S.).

Marked increase of fibrous tissue is noted around the small vessel and radiating out from this into the masses of Gaucher cells are strands of fibrous tissue. (Hæmatoxylin and Eosin.) 

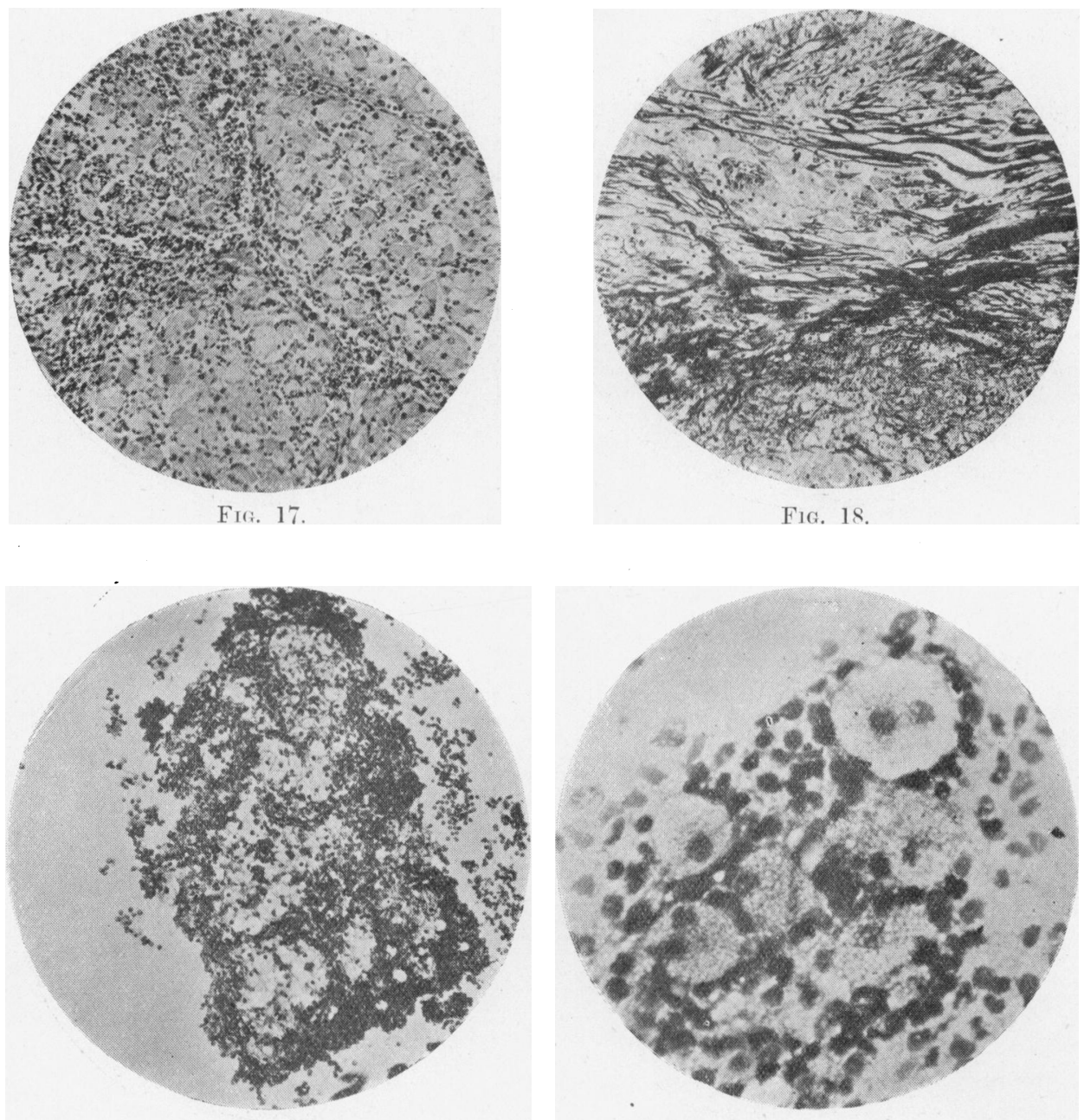

FIG. 19.

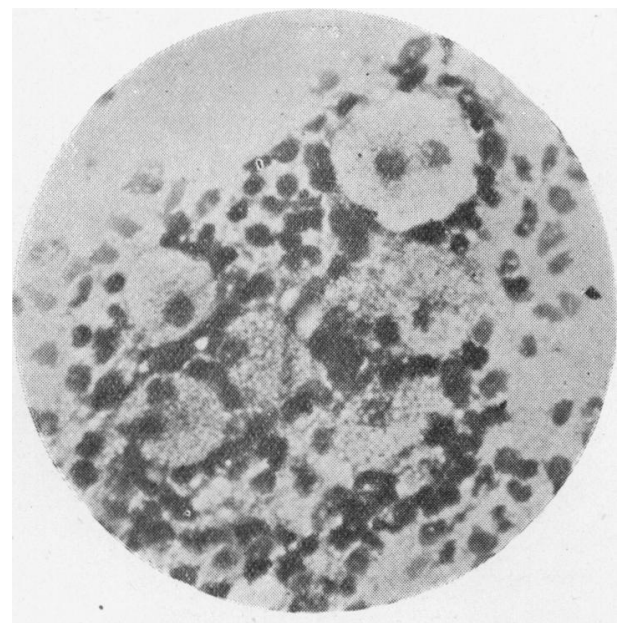

FIG. 20.

Fig. 17.--Section of Spleen from Case 1 (M.F.).

The pulp spaces are packed with Gaucher cells, a few of which are seen in the small sinusoids. Compare the appearance of this section (from a young child) with that of Fig. 18 (from an adult). (Mallory's stain.)

Fig. 18.- Section of Spleen fron. Case 5 (Adult).

Dense irregular fibrosis is seen throughout the section though numerous clumps of Gaucher cells are still present. (Iron hæmatoxylin.)

Fig. 19.-Section of Material Obtained by Splenic Punctlre from Case 2 (G.L.). A small piece of splenic tissue is seen in which numerous Gaucher cells are present in the pulp spaces. (Hæmatoxylin and Eosin.)

Fig. 20.-Film of Material Obtained by Splenic Puncture from Case 2 (G.L.).

A few large cells, some of which have more than one nucleus and showing a reticulated appearance of their protoplasm, are noted. The figure shows the size of the large cells as compared with the small, darkly-staining red blood cells. (Hæmatoxylin and Eosin.) 
of the body-weight instead of $1 / 400$. Enlargement of the superficial lymphglands does not, as a rule occur, but it is of interest to note that those in the thorax and abdomen are usually enlarged, the extent of their enlargement depending on the degree of the involvement by the Gaucher cells.

Liver. A moderate enlargement of the liver is almost constantly present and this is of great importance in view of the similarity of Gaucher's disease to Banti's disease where, except in the early stages, the liver is small. Mandelbaum, however, has reported one fatal case in which the liver was not enlarged. In this case, also, there was no leucopenia, and ascites was present. The diagnosis was confirmed by histological examination, Gaucher cells being found in both liver and spleen.

Blood. There is no more constant feature in Gaucher's disease than the leucopenia which appears early and persists throughout. Excepting the anomalous case just mentioned, it has been present in all the published cases. Regarding the types of leucoytes present, there is nothing characteristic of the disease, although it is common in our experience to find a small percentage of myelocytes. As a rule the red cells are not greatly diminished, no nucleated red cells are present, and anæmia cannot be said to be a feature although there does occasionally occur an anæmia of the chlorotic type which may be very severe (Case 1). The fragility of the red cells is unaltered. There appears to be a definite tendency to hæmorrhages, especially from the mucous membranes (epistaxis, bleeding gums, bleeding lips, etc.), and in all of our cases this was very noticeable. In two of the cases there was considerable difficulty in controlling bleeding after the removal of carious teeth, and in Case 1, oozing of blood from the transfusion wound at the ankle persisted for several days. Unfortunately, the clotting time was determined in only one instance (Case 2), where it was found to be 128 seconds, the normal with the method used being 100 seconds.

Skin and Eyes. A brownish-yellow discolouration of the skin limited to the exposed parts has frequently been described, but is often absent. In one of our cases (Case I) the skin had an icteroid tint such as is usually seen in patients suffering from a severe anæmia. In another case (Case IV) there was a definite jaundice and in Case $\mathrm{V}$ pigmentation of the skin over the fronts of both legs was observed. In the others, no discolouration of the skin was noted.

Many writers have reported the presence of a brownish-yellow wedgeshaped thickening of the conjunctivæ affecting first the nasal side and later the temporal side. Brill and Mandelbaum (14) state that they have never seen a case in which it was absent. In our cases, although looked for carefully, it was never detected.

Later Manifestations. Pain of a dragging nature may be present and is said to be due to the weight of the enlarged spleen. Pain in the splenic region and localised areas of tenderness over the splenic tumour may occur, and are due probably to areas of perisplenitis. After many years there is often obtained a history of pain in the ends of the long bones, especially the lower ends of the femora, and pathological fractures have frequently occurred. 
Course. The disease is in the majority of instances chronic and slowly progressive, although a fatal termination may ensue at a comparatively early age ( $c f$. Case I). Schlagenhaufer's $\left(^{(6)}\right.$ patient lived for 37 years after the diagnosis had been made, and Brill and Mandelbaum (14) in 1913, refer to a sister of one of their cases in whom the disease is known to have existed for 24 years. The last writers give the average duration of life as $19 \frac{1}{2}$ years, but such a figure can only be a very rough approximation. Regarding the course of the disease after splenectomy, there seems to be no definite proof that the life of the patient is prolonged by the operation, although in many cases the symptoms of pain and discomfort are relieved.

\section{Diagnosis.}

It is probably unnecessary here to comment on the possibility of confusion in diagnosis between Gaucher's disease and such conditions as leukæmia, Hanot's cirrhosis, pernicious anæmia, tuberculosis and Hodgkin's disease. Special attention to the blood examination, the superficial lymph-glands, and the course of the disease will in the majority of cases serve to differentiate these conditions from Gaucher's disease.

The association of a splenic enlargement and a leucopenia, however, in an infant or a child should always suggest the possibility of Gaucher's disease to the clinician, but it must also be remembered that Banti's disease, particularly in the early stages, may present a picture so similar that from the clinical findings alone, it may be impossible to differentiate between the two conditions. Both maladies are associated with splenic enlargement and leucopenia. Banti's disease is not familial, does not appear before the beginning of the second dentition, and as a rule runs a more rapid course. The liver, except in the early stages, is not enlarged, and jaundice and ascites are of common occurrence. Furthermore, an anæmia is a much more distinctive feature of Banti's disease than of Gaucher's disease. Profuse gastric hæmorrhages from œsophageal varices are of frequent occurrence in Banti's disease but in Gaucher's disease, although bleeding from mucous membranes occurs frequently, large hæmorrhages are rare.

Certain cases of acholuric jaundice in children may also cause confusion in diagnosis, especially those cases in which there occurs a leucopenia. A history of erythroblastic blood crises with the rapid development of anæmia aids in the differentiation of the two conditions but the absolute diagnosis of acholuric jaundice rests on the detection of the increased fragility of the red cells. This fragility is unchanged in Gaucher's disease.

Splenic Puncture. If there is doubt or if confirmation of the diagnosis is wanted, valuable information may be gained by obtaining splenic tissue for histological examination by means of splenic puncture. This procedure was first employed by Bernstein. ${ }^{(15)}$ in 1915 to diagnose Gaucher's disease but apparently has not come into general use, although the method would seem to be devoid of danger. We have employed it on several occasions, and in conditions other than Gaucher's disease, with no untoward results. 
The method adopted is as follows:-Having fixed the spleen firmly against the lower border of the ribs, a large bored needle with syringe attached is plunged into the substance of the spleen and a portion of splenic tissue sucked up into the bore of the needle in much the same way as a sample of cheese is taken. The needle is then withdrawn while still keeping up a negative pressure in the syringe. As a precautionary measure, a sterile swab is held over the site of puncture and firm pressure applied for a few minutes. The contents of the syringe and needle are now diluted with 6 to $8 \mathrm{cc}$. of distilled water to lake the red cells, and the whole gently washed into a centrifuge tube which is now spun at a low speed to get all the cells and pieces of splenic tissue to the bottom. A small amount of this sediment is pipetted off and from this films are made and fixed in formalin, after which they are stained by hæmatoxylin and eosin (Fig. 20) and in suspected cases of Gaucher's disease or Niemann's disease by one of the fat stains. Sufficient formalin is now added to the material left in the tube to make a concentration of approximately 10 per cent., which causes a fairly good coagulum to form. After the usual dehydration and clearing processes, the deposit is embedded in paraffin; all these steps are carried out in the centrifuge tube which, when the paraffin has set, is broken and the block removed. Ribbons are cut and every tenth section is stained and examined for splenic tissue (Fig. 19).

\section{Pathogenesis.}

Gaucher, when he originally described this disease, considered it to be of the nature of a tumour primarily of splenic origin. Collier, likewise, held this opinion and inclined to the view that the condition was an endothelioma. The Morbid Growths Committee of the London Pathological Society, however, to whom Collier submitted his preparations decided that the lesion was not a tumour and called attention for the first time to the fact that the lymphatic glands were also affected. About this time, also, Cornil ( $\left.{ }^{16}\right)$ stated that the lesions described by Gaucher could not be a primary endothelioma, and expressed the opinion that it was a primary hypertrophy of the spleen with proliferation of reticular tissue.

The outstanding characteristic of Gaucher's disease is the presence of large cells with darkly staining nuclei, occasionally multiple, and with a finely reticulated protoplasm, found in all the tissues and organs in which the reticuloendothelium is prominent, namely, spleen, liver, lymph-glands and bone marrow. The wide-spread occurrence of the cells throughout the substance of the lymphatic glands rather than masses of cells in the peripheral sinuses is more typical of a system disease than of a tumour. In some cases the spleen has been little affected, the lesions being chiefly in the bones and liver, as reported by Piney $\left({ }^{17}\right)$.

Our first case (M.F.) corresponds to the general description of Gaucher's disease, the character and distribution of the large cells being typical. The lesions in the spleens of the other cases correspond histologically and microchemically to those of the first case. None of the cases showed any evidence of syphilis or tuberculosis, although the latter disease is cited by Schlagenhaufer ${ }^{5}$ ) 
and Ewing $\left({ }^{18}\right)$ as being an ætiological factor. Aerobic and anærobic cultures made from the spleens excised at operation remained sterile, and no spirochætes were found on darkground examination or in stained films. In subcutaneous inoculation into guinea-pigs of splenic material and, in the first case, of mesenteric and bronchial glands ground up in saline, no lesions were noted when the animals were killed eight weeks later.

Origin of Gaucher Cells. There has been much variance of opinion regarding the origin of the Gaucher cells, American writers favouring endothelium as well as reticulum, while the German writers are of the opinion that these cells arise from the reticulum only. From our studies we are inclined to agree with the latter view. We have noted transition stages between reticular cells and Gaucher cells in the Malpighian bodies of the spleen and also in the lymphatic glands. Further, in all the organs and tissues where the large cells were met, they always maintained a very close relationship to the reticulum. Mandelbaum ( $\left.{ }^{19}\right)$ noted the close relationship between the Gaucher cells and certain large cells in the lymphatic germ-centre, and he drew the conclusion that these large cells were members of the lymphatic series, and that they gave rise to Gaucher cells. In histological preparations of normal spleens from children as well as of spleens from cases of Gaucher's disease, we have observed in the germ-centres of the Malpighian bodies and lymphatic glands, similar cells, generally more oval than round and occasionally having a very close relationship to reticular fibres but differing in their staining and phagocytic reactions from true lymphatic germ-cells. We have regarded such cells as reticular in origin, and have also observed, as noted above, what appeared to be transition stages between such cells and Gaucher cells. The first case (Fig. 2) supports this view, the germ-centres being entirely replaced by Gaucher cells. Downey's work, quoted by Mandelbaum ( ${ }^{7}$ ), points to the Gaucher cells taking origin from the reticulum in the lymphatic germ-centres, and also from the reticular structures around lymph follicles. With this view, we are in complete agreement, and in the first case (M.F.), where the lymphatic glands were studied, we have noted changes similar to those quoted by Mandelbaum, namely, thickening of the reticulum and, in places, swelling of the reticular fibres. Another point in favour of the reticular origin of such cells is the appearance in staining of the cells by potassium ferrocyanide and hydrochloric acid, the Gaucher cells either showing no iron reaction or a very slight diffuse reaction, whereas in the endothelial cells, a granular reaction is obtained. Pick ${ }^{\left({ }^{2}\right)}$ has also commented on this point.

Lipoid Content of Gaucher Cells. One of the most characteristic features of the Gaucher cells is their reticulated appearance, due to a lipoid-like substance which they contain. Regarding the nature of this substance, much controversy has arisen, and Mandelbaum ( ${ }^{7}$ ) who has written extensively on the question has always been emphatic that the cells do not give the micro-chemical reaction for lipoids, although he states that the organs which are affected have a high lipoid content (lecithin and cholesterin in combination with protein of a complex nature). Similar results have been reported by Epstein ( ${ }^{20}$ ) who isolated a crystallising cerebroside which he identified as kerasin, and in 
addition, found phosphatides present, though he failed to find either lecithin or cholesterin. Bloom ( ${ }^{21}$ ) also found that the cells when stained with Sudan III and hæmatoxylin gave a slight greyish-yellow tinting of the protoplasm, although he decides against the cells containing lipoids. In our cases, we have found that while the reaction to lipoid stains is not typical of the lipoids met with in ordinary histological work, still it appeared as if the cells did take up some of the lipoid stain as noted by Bloom. On further experiments, we found that by heating frozen sections to $100^{\circ} \mathrm{C}$. in water or glycerine and then staining with Sudan III or Nile Blue, the cells took up the fat stain to a slight degree, and anisotropic bodies were seen in the cells. This fact has not been previously noted and would appear to be due to a hydrolysis caused by the heating, or what is more probable, a melting and running together into large globules of the lipoid substances which are present in the cells in a diffuse phase. Further studies of these large cells will be published at a later date. In the meantime, however, it is our opinion that the Gaucher cells do contain a substance of a fatty nature and we suggest that the disease is a reaction of the cells of the reticulo-endothelial system to some metabolic error in lipoid metabolism.

Although it is generally believed that the large cells are pathognomonic of Gaucher's disease, it must be remembered that somewhat similar cells do occur in other conditions and on several occasions have been confused with Gaucher cells. For example, in diabetes with lipæmia, lipoid substances may be stored in the reticulo-endothelial cells of the spleen and in some cases there is such a proliferation of the cells that splenomegaly results. These cells may readily be confused with Gaucher cells. Moreover, after feeding animals with cholesterol over a long period of time, numerous large cells containing doubly refractile lipoids appear in the spleen, liver and lymph-glands. The similarity of these cells to those seen in Gaucher's disease is so marked that Aschoff ( ${ }^{22}$ ) called the condition " pseudo-Gaucher." In Niemann's disease ( ${ }^{23}$ ) cells which give the usual reactions for lipoids are found throughout many organs including the suprarenals while the liver in this condition shows no evidence of cirrhosis. As already mentioned, the material present in the large cells in Gaucher's disease is probably of a complex lipoid nature, and it would seem that the cells of the reticulo-endothelial system store these substances in much the same way as, in vital staining of animals, the injected dye is picked out from the blood and stored by such cells. In the diseased condition, however, the storage capacity becomes overtaxed and there results a great proliferation of cells of reticulo-endothelial origin. If such a view is correct, it brings the histological lesions met with in diabetes with lipæmia, in the experimentally produced cholesterolæmia, in Niemann's disease and in Gaucher's disease, all into the same category, i.e., a reaction on the part of the reticular cells to some abnormal product of lipoid metabolism, the difference in the various diseases depending for the most part on the nature of the lipoid substances concerned. The cirrhosis of the liver would appear to be due to necrosis occurring in masses of Gaucher cells, and also to the laying down of collagen in a hypertrophic reticulum. 


\section{ConClusions.}

1. Five cases of Gaucher's disease are reported and the clinical and pathological features discussed.

2. The diagnosis of Gaucher's disease can be readily confirmed by the histological examination of splenic tissue obtained by splenic puncture. The procedure adopted is described.

3. The disease is probably a reaction on the part of the reticulo-endothelial system to some abnormal or unwanted product of lipoid metabolism.

4. Gaucher's disease, Niemann's disease, changes observed in experimentally produced cholesterolæmia and in diabetes with lipæmia, fall, we believe, into the same category, depending on the nature of the lipoids involved.

Splenectomy was performed in these cases by Mr. Alex. MacLennan, Visiting Surgeon, Royal Hospital for Sick Children, Glasgow, to whom we are indebted for permission to make use of his reports. We have also much pleasure in acknowledging the grateful help and advice of Prof. Robert Muir and Prof. Leonard Findlay.

\section{REFERENCES.}

1. Gaucher, E., Thèse de Paris, 1882. (Quoted by F. S. Mandelbaum, J. Exp. Med., N.Y., 1912, XVI, 797.)

2. Collier, W., Trans. London Path. Soc., 1895, XLVI, 148.

3. Picou, R., and Ramond, F., Arch. de. Méd. Exper. et d'anat. Path., Paris, 1896, VIII, 168.

4. Bovaird, D., Amer. Jour. of Med. Science, Philadelphia and New York, 1900, CXX, 377.

5. Brill, N. E., Mandelbaum, F. S., and Libman, E., Proc. New York Path. Soc., 1904, IV, 143; and Amer. Jour. Med. Sci., Philadelphia and New York, 1905, CXXIX 491.

6. Schlagenhaufer, F., Virchow's Arch. f. Path. Anat., Berlin, 1907, CLXXXVII, 125.

7. Mandelbaum, F. S., Amer. Jour. Med. Sci., Philadelphia and New York, 1919, CLVII, 366.

8. Knox, J. H. M., Wahl, H. R., and Schmeisser, H. C., Johns Hopkins Bull., Baltimore, 1916, XXVII, 1.

9. De Lange, C., and Schippers, J. C., Nederl. Tijdschr. v. Geneesk., Haarlem, 1917, I, 890.

10. De Lange, C., and Schippers, J. C., Jahr. f. Kinderheilk., Berlin, 1917, LXXXVI, 459 ; and Amer. Jour. Dis. Child., Chicago, 1918, XV, 249.

11. Pick, L., Ergeb. d. inn. Med. u. Kinderheilk., Berlin, 1926, XXIX, 519.

12. Pick, L., Virchow's Arch. f. Path. Anat. u. Physiol., Berlin, 1925, CCLIV, 782.

13. Epstein, E., Virchow's Arch. f. Path. Anat. u. Physiol., Berlin, 1924, CCLIII, 157.

14. Brill, N. E., and Mandelbaum, F. S., Amer. Jour. Med. Sci., Philadephia and New York, 1913, CXLVI, 863.

15. Bernstein, E. P., Jour. Amer. Med. Assoc., Chicago, 1915, LXIV, 1907.

16. Cornil, Bull. de la Soc. Anat., Paris, June 28, 1895, 532.

17. Piney, A., Personal Communication.

18. Ewing, J., Neoplastic Diseases, Philadelphia and London, 1922, 313.

19. Mandelbaum, F. S., Jour. Exper. Med., New York, XVI, 797.

20. Epstein, E., Wein Klin. Wochenschr., Vienna, 1924, XXXVII, 1179.

21. Bloom, W., Amer. Jour. Path., Boston, 1925, I, 595.

22. Aschoff, L., and Kiyono, K., Folia Homatol., Leipzig, 1913, XV, 383.

23. Niemann, A., Jahrb. f. Kinderheilk, Berlin, 1914, LXXIX, 1, 